\title{
Melanoma and non-melanoma skin cancer among patients who attended at King Khalid University Hospital in Riyadh, Saudi Arabia from 2007 - 2018
}

\author{
Khalid A. Arab, MD, Amjad AlRuhaili, MD, Tariq AlJohany, MD, Reema S. AlHammad, MD.
}

\begin{abstract}
الأهداف: تقييم مدى انتشار سرطان الجلد وسرطان الجلد غير الميلانيني

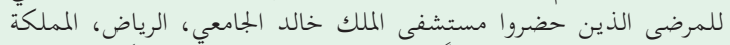

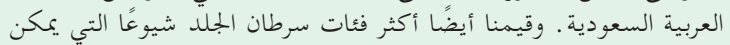

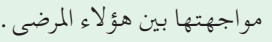

المنهجية : أجرى الباحثون دراسة استعادية شملت جميع المرضى ( السعوديين

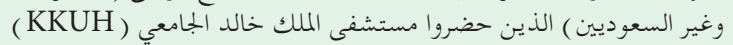

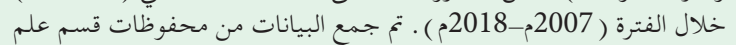

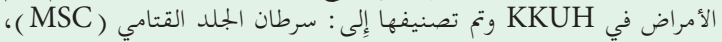

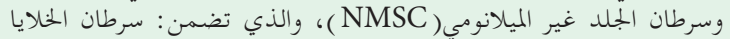

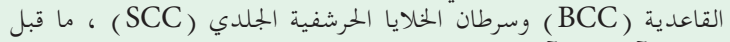

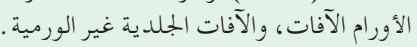

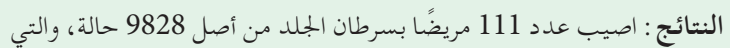

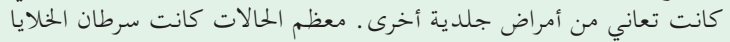

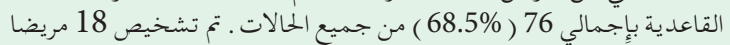

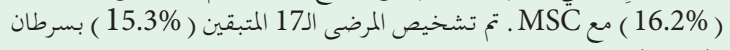
الخلايا الحرشفية.

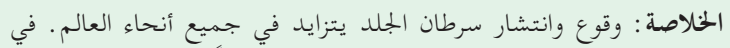

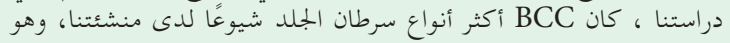
مشابه لغالبية الدراسات الدولية الأخرى.
\end{abstract}

Objectives: To assess the prevalence of melanoma and non-melanoma skin cancer for patients attended King Khalid University Hospital, Riyadh, Saudi Arabia. We are also assessing the most common category of skin cancer to be encountered among those patients.

Methods: The authors conducted a retrospective study including all patients (Saudi and non-Saudi) who attended King Khalid University Hospital (KKUH) at the period of (2007-2018). Data were collected from archives of Pathology Department at KKUH and categorized into: melanoma skin cancer (MSC), non-melanoma skin cancer (NMSC), which included: basal cell carcinoma (BCC) and squamous cell carcinoma (SCC), pre-neoplastic lesions, and non-neoplastic skin lesions.
Results: A total of 111 patients were reported to have skin cancer out of 9828 cases, which had other skin pathology. Majority of cases were basal cell carcinoma with a total number of $76(68.5 \%)$ of all cases. 18 patients (16.2\%) were diagnosed with MSC. The remaining 17 patients $(15.3 \%)$ were diagnosed with squamous cell carcinoma.

Conclusion: Skin cancer prevalence and incidence is increasing worldwide. In our study, BCC was the most common type of skin cancer to be reported in our institute, which is similar to the majority of other international studies.

Keywords: MSC, NMSC, BCC, SCC, KKUH

Saudi Med J 2020; Vol. 41 (7): 709-714

doi: 10.15537/smj.2020.7.25138

From the Division of Plastic Surgery (Arab, AlRuhaili), Department of Surgery, from the Department of Pathology (AlJohany), College of Medicine, King Saud University; and from the College of Medicine (AlHammad), King Khalid University Hospital, King Saud University, Riyadh, Kingdom of Saudi Arabia.

Received 10th September 2019. Accepted 10th April 2020.

Address correspondence and reprint request to: Dr. Reema $S$. AlHammad, College of Medicine, King Saud University, Riyadh, Kingdom of Saudi Arabia. E-mail: alhammadreema@gmail.com ORCID ID: https://orcid.org/0000-0001-8053-9628

A $\mathrm{n}$ increase in the incidence of melanoma and nonmelanoma skin cancer (NMSC) worldwide has been reported by different studies. Non-melanoma skin cancer is considered the most common type of cancer among Caucasians. ${ }^{1}$ Nowadays, more than one million new cases of skin cancer are reported each year. Non-melanoma skin cancer category consists of 2 main types. ${ }^{2}$ The most common is basal cell carcinoma (BCC), which represents the majority of cases of NMSC by $75 \% .^{3,4}$ The second main type is squamous 
cell carcinoma (SCC), which represents the majority of the remainder of the cases of NMSC. ${ }^{5}$ There are many risk factors for developing skin cancer, and it is usually a combination of environmental, genetic and phenotypic features. ${ }^{6}$ The incidence rate of melanoma skin cancer (MSC) has been steadily increasing worldwide. ${ }^{7}$ Generally, the incidence of NMSC (BCC and SCC) is higher than the melanoma incidence by $18-20$ times. ${ }^{8}$ Nowadays, malignant melanoma accounted for 232,000 new cases worldwide (1.6\% of new cancers). Fair skin is considered a risk factor for developing skin cancer in Europe. The highest incidence of skin cancer is documented in both males $(40.3$ per 100,000$)$ and females $(30.5$ per 100,000$)$ in Australia/New Zealand with very low incidence rates (below 0.5 per 100,000 in both males and females) are estimated in SouthEastern Asia and South-Central Asia. ${ }^{9-11}$ Screening for susceptible patients and identifying the risk factors associated with the development of these skin cancers will help in eliminating the disease and reducing its morbidity rates. ${ }^{12}$ One of the most important risk factors for developing skin cancer is ultraviolet (UV) light exposure..$^{13}$ An intensive UV exposure in childhood and adolescence was causative for the development of BCC. The development of melanoma appears to be related to intense, intermittent sun exposure as well. ${ }^{14}$ Other risk factor is precursor lesions, which are not appreciated in cases of BCC, but seen in cases of SCC. This includes actinic keratosis and SCC in situ. Melanoma may arise from dysplastic or atypical nevi and rarely from benign nevi. ${ }^{15}$ Skin cancer has a large financial burden on health care services, and primary prevention programs of this disease would take a long period to start showing results. ${ }^{16}$ Our study aim is to provide the estimated prevalence of all skin cancer patients, through the registered cases at King Khalid University Hospital, Riyadh, Saudi Arabia, from 2007 to 2018.

Methods. The Institutional Review Board at King Saud University Medical City approved the study. We have conducted a retrospective study. Patients included in this study were identified from King Khalid University hospital registry. Our data was collected from histopathological samples of all types of skin biopsy in the Pathology Department, King Khalid University Hospital for the past 11 years (2007 - 2018).

Disclosure. Authors have no conflict of interests, and the work was not supported or funded by any drug company.
All patients with skin sample or biopsy as a diagnostic method were included. We excluded patients presented to the hospital for other medical condition, patients with any other cutaneous malignancies, and patients who underwent any medical treatment for skin abnormality without a pre-diagnostic test. All skin samples and biopsies reports were addressed, but only skin cancer reports were included for analysis. A new Excel sheet was established were data was entered and coded to ensure confidentiality. The data was plotted based on demographics, which included the file number, laboratory number of the biopsy or sample, age, gender, and nationality. Other parameters were measured as well; including information on the nature of lesion, its type, size, site, borders, depth, and lymphovasular invasion. Risk factors were identified in each case that includes history of previous skin cancer, exposure to radiation or long exposure to sunlight, use of immunosuppressant and metastasis. No follow-up was conducted from our team. Data were then analyzed using the Statistical Package for Social Sciences version 24.0 (IBM, armonk, NY, USA).

Results. A total of 9828 cases with skin abnormality on their histopathology reports were revised. Approximately 111 cases had documented skin cancer on their report and were included in our study. The incidence rate was steady throughout the years (Table 1). Majority of cases were BCC with a total number of 76 $(68.5 \%)$ of all cases of skin cancer. The remainder was MSC with total number of $18(16.2 \%)$ cases followed by 17 cases of SCC (15.3\%). Basal cell carcinoma was among the age group of $63 \pm 14$ years. The remainder SCC and melanoma patients were among a younger age group (Table 2).

Basal cell carcinoma was more common in males (53.9\%) compared to females (46.1\%). Approximately $52.9 \%$ and $72.2 \%$ of the patients who had SCC and melanoma were females. Basal cell carcinoma and SCC showed a strong correlation between history of immunosuppressant use and development of skin cancer, with a $p<0.0001$. Most cases of BCC presented as an ulcer $(65.8 \%)$, with a $p<0.0001$. Squamous cell carcinoma patients presented mostly as a non-ulcerated nodule $(76.5 \%)$, with a $p<0.0001$. The majority of the patients diagnosed with melanoma presented to the clinic with a pigmented lesion $(77.8 \%)(p<0.0001)$.

The nose was the most common anatomical location of the diagnosed BCC patients (26.3\%) followed by the face $(19.7 \%)$, scalp $(14.5 \%)$, back $(10.5 \%)$, and 
Table 1 - Incident rate of 9828 cases with skin abnormality.

\begin{tabular}{lcrc}
\hline Years & $\begin{array}{c}\text { Total number } \\
\text { of samples }\end{array}$ & $\begin{array}{c}\text { Number of cases with } \\
\text { skin cancer } \\
\text { n }\end{array}$ \\
\hline 2007 & 788 & 5 & $(0.6)$ \\
2008 & 802 & 11 & $(1.4)$ \\
2009 & 755 & 6 & $(0.8)$ \\
2010 & 934 & 9 & $(1.0)$ \\
2011 & 832 & 11 & $(1.3)$ \\
2012 & 1070 & 8 & $(0.8)$ \\
2013 & 790 & 6 & $(0.8)$ \\
2014 & 837 & 11 & $(1.3)$ \\
2015 & 695 & 16 & $(2.3)$ \\
2016 & 764 & 9 & $(1.2)$ \\
2017 & 820 & 15 & $(1.8)$ \\
2018 & 741 & 4 & $(0.5)$ \\
Total & 9828 & 111 & $(1.2)$ \\
\hline
\end{tabular}

lastly were the eyes (9.2\%). $23.5 \%$ of the SCC cases were located in the face and scalp. Acral melanoma represents almost $56 \%$ of all melanoma located in the lower extremity followed by the upper extremity.

The majority of BCC skin cancer histopathology indicated well-defined margins. This resulted in less aggressive disease with less recurrence. Only 27\% were recurrent BCC. Squamous cell carcinoma showed $(52.9 \%)$ of ill-defined margins and (47.1\%) of welldefined margins in the studied samples. Melanoma sample indicated more ill-defined margins (94.4\%), with a $p$ value of $<0.0001$, and only $(5.6 \%)$ with a welldefined border. Lymph-vascular invasion was primarily found in melanoma, which has the highest rate of invasion by $(61.1 \%)$

Basal cell carcinoma presented with the smallest surface area on the skin with $1.328 \mathrm{~cm} \pm 1.70 \mathrm{~cm}$ for lesion size. This correlates with the lower risk of recurrence. Squamous cell carcinoma surface area was $3.674 \mathrm{~cm} \pm 6.61 \mathrm{~cm}$, and the highest surface area was melanoma $6.989 \mathrm{~cm} \pm 8.89 \mathrm{~cm}$.

Table 2 - Patients demographics and analysis.

\begin{tabular}{|c|c|c|c|c|}
\hline \multirow[t]{2}{*}{ Variables } & \multicolumn{3}{|c|}{ Groups } & \multirow[t]{2}{*}{$P$-value } \\
\hline & $\begin{array}{c}\text { Melanoma } \\
\qquad(\mathrm{n}=18) \\
16.2 \%\end{array}$ & $\begin{array}{c}\text { Non-melanoma } \\
\quad(B C C) \\
(n=76) 68.5 \%\end{array}$ & $\begin{array}{c}\text { Non-Melanoma } \\
\text { (SCC) } \\
(n=17) 15.3 \%\end{array}$ & \\
\hline \multicolumn{5}{|l|}{ Nationality } \\
\hline Saudi & $17(94.4)$ & $64(84.2)$ & $13(76.5)$ & 0.330 \\
\hline Non-Saudi & $1(5.6)$ & $12(15.8)$ & $4(23.5)$ & \\
\hline Age $($ mean $\pm S D)$ & $56.333 \pm 15.54$ & $63.118 \pm 14.58$ & $58.529 \pm 18.097$ & 0.176 \\
\hline Gender & & & & 0.135 \\
\hline Male & $5(27.8)$ & $41(53.9)$ & $8(47.1)$ & \\
\hline Female & $13(72.2)$ & $35(46.1)$ & $9(52.9)$ & \\
\hline Metastasis & $11(61.1)$ & $1(1.3)$ & $3(17.6)$ & $<0.0001$ \\
\hline Presented as nevus & $14(77.8)$ & $0(0)$ & $1 \quad(5.9)$ & $<0.0001$ \\
\hline Immune suppression $\mathrm{Hx}$. & $8(44.4)$ & $73(96.1)$ & $15(88.2)$ & $<0.0001$ \\
\hline Lymphovascular invasion & $11(61.1)$ & $4(5.3)$ & $2(11.8)$ & $<0.0001$ \\
\hline Presented as lesion & $1 \quad(5.6)$ & $25(32.9)$ & $13(76.5)$ & $<0.0001$ \\
\hline Presented as ulcer & $3(16.7)$ & $50(65.8)$ & $3(17.6)$ & $<0.0001$ \\
\hline Borders & & & & $<0.0001$ \\
\hline Ill defined & $17(94.4)$ & $29(38.2)$ & $9(52.9)$ & \\
\hline Well defined & 1 (5.6) & $47(61.8)$ & $8(47.1)$ & \\
\hline Primary & $12(66.7)$ & $55(72.4)$ & $13(76.5)$ & 0.807 \\
\hline Recurrent & $6(33.3)$ & $21(27.6)$ & $4(23.5)$ & \\
\hline
\end{tabular}


In regard to the depth, SCC has a depth of $0.759 \mathrm{~cm} \pm 0.905 \mathrm{~cm}$, while the depth of melanoma cases found to be $0.639 \mathrm{~cm} \pm 0.66 \mathrm{~cm}$. Basal cell carcinoma presented with the lowest depth of $0.404 \mathrm{~cm} \pm 0.355 \mathrm{~cm}$.

Metastasis of cancer were found to be statistically significant and highest among melanoma cases by $61.1 \%$ with $p<0.0001$. Approximately $17.6 \%$ of SCC had metastasis. Lastly, with the lowest metastasis rate comes BCC by $1.3 \%$, which is found to be significant with a $p<0.0001$.

Discussion. This study was conducted to assess the epidemiology of skin cancer among patients who attended at King Khalid University Hospital, Riyadh, Saudi Arabia. Skin cancer prevalence rate is increasing worldwide. ${ }^{17,18}$ It was proven that skin cancer in general is more common among Caucasian population. ${ }^{12,19}$ In the United States, NMSC reported to be the most common type of skin cancer. ${ }^{17}$ Australia came first as highest incidence rate and prevalence of skin cancer worldwide. ${ }^{20,21}$ It was also found that BCC and SCC are the most diagnosed type of skin cancer in Australia. ${ }^{21} \mathrm{~A}$ study carried out in Italy reported that incidence rate of BCC is the highest. ${ }^{22}$ Another study conducted in Vaud, Switzerland, reported BCC to be the most common type reported among both males and females. ${ }^{23}$ While in Germany, it was reported that $80 \%$ of skin cancer cases were found to be $\mathrm{BCC} \cdot{ }^{23} \mathrm{~A}$ study conducted in Northern Ireland, reported BCC to be the most common type among the skin cancer cases. It was also found to be more common among males than females. ${ }^{24}$

Asia is a big geographical area, which explains different numbers of incidence rate and prevalence. Unfortunately, there are no enough studies conducted among Asian population to assess incidence rate and prevalence of skin cancer. ${ }^{25}$ The report of cases is less in developing countries due to limited financial resources. A study carried out in Singapore, reported BCC as the most common skin cancer, followed by SCC and melanoma. ${ }^{26}$ A study conducted in Saudi Arabia from 1990 to 2003, reported 193 patients to have skin cancer based on the histopathological diagnosis, BCC represented $41 \%$ of cases, SCC $29 \%$, and melanoma was $4.1 \%$. Male gender was predominant in this study. ${ }^{27}$ Our study came in concordance with other international and local studies and shows the higher incidence of BCC compared to other skin cancer types. It also shows male predominance. Our data shows higher number of cases of melanoma than
SCC. Ultraviolet light exposure for a long period of time reported to be the main contributing factor to develop BCC specifically, and skin cancer in general. ${ }^{25}$ Ultraviolet light exposure and sunlight exposure could vary among people. ${ }^{28}$ Unfortunately, UV light exposure is difficult to assess clinically. ${ }^{29}$ In our study, we could not assess all patients for UV light exposure, since it was a retrospective study. Use of immunosuppressive treatment in general has a significant correlation in developing malignant neoplasm in general. ${ }^{30}$ In our study, it was significant correlation between the use of immunosuppressive treatment and developing skin cancer. Approximately $96.1 \%$ of our patient with BCC had history of immunosuppressant use. Approximately $88.2 \%$ with SCC had positive history of immunosuppressive conditions.

Skin cancer is usually found on sun-exposed areas, such as head and neck. Multiple studies reported skin cancer to appear more in those areas of human body. ${ }^{15,25,26,31-44}$ In our study we had similar results, were NMSC reported to appear more frequently present in the head and neck. Melanoma was most commonly presented in the lower limb.

Studies reported that BCC has the least metastatic rate followed by SCC. Melanoma has the highest rate of metastasis. ${ }^{45,46}$ Our study shows similar results.

Study limitations. Study included low sample size because the scope of the study was limited to only patients attending King Khalid University Hospital in Riyadh, Saudi Arabia.

The study would benefit from expanding the sample size to include more hospitals in Riyadh and Saudi Arabia in general. In the future, the study can include more hospitals and higher sample size with focus on subtypes of each category of skin cancer. It can also be conducted prospectively to assess sunlight exposure, mortality, and morbidity rate.

In conclusion, skin cancer prevalence and incidence is increasing worldwide. In our study, we found similar results to international studies, were BCC was the most common type of skin cancer to be reported.

\section{References}

1. Alam M, Nanda S, Mittal BB, Kim NA, Yoo S. The use of brachytherapy in the treatment of nonmelanoma skin cancer: a review. J Am Acad Dermatol 201 1; 65: 377-388.

2. Nguyen TH, Ho DQD. Nonmelanoma skin cancer. Curr Treat Options Oncol 2002; 3: 193-203.

3. Ting PT, Kasper R, Arlette JP. Metastatic basal cell carcinoma: Report of two cases and literature review. J Cutan Med Surg 2005; 9: 10-15. 
4. Lo JS, Snow SN, Reizner GT, Mohs FE, Larson PO, Hruza GJ. Metastatic basal cell carcinoma: Report of twelve cases with a review of the literature. J Am Acad Dermatol 1991; 24 (5 Pt 1): 715-719.

5. Macbeth AE, Grindlay DJC, Williams HC. What's new in skin cancer? An analysis of guidelines and systematic reviews published in 2008-2009. Clin Exp Dermatol 2011; 36: 453-458.

6. Kricker A, Armstrong BK, English DR, Heenan PJ. Does intermittent sun exposure cause basal cell carcinoma? a casecontrol study in Western Australia. Int J Cancer 1995; 60: 489-494.

7. Markovic SN, Erickson LA, Rao RD, Weenig RH, Pockaj BA, Bardia A, et al. Malignant melanoma in the 21st century, part 1: Epidemiology, risk factors, screening, prevention, and diagnosis. Mayo Clinic Proceedings 2007; 3: 364-380.

8. Miller DL, Weinstock MA. Nonmelanoma skin cancer in the United States: Incidence. J Am Acad Dermatol 1994; 30: 774-778.

9. Ferlay J, Soerjomataram I, Dikshit R, Eser S, Mathers C, Rebelo M, et al. Cancer incidence and mortality worldwide: Sources, methods and major patterns in GLOBOCAN 2012. Int J Cancer 2015; 136: E359-E386.

10. Battistini E, Battistini S, Barachini P. Epidemiology of melanoma and non melanoma skin cancer in the provinces of Pisa and Massa-Carrara from 1997 to 2002. Giornale Italiano di Dermatologia e Venereologia 2005; 140: 33-44.

11. Staples MP, Elwood M, Burton RC, Williams JL, Marks R, Giles GG. Non-melanoma skin cancer in Australia: The 2002 national survey and trends since 1985. Med J Aust 2006; 184: 6-10.

12. Diepgen TL, Mahler V. The epidemiology of skin cancer. $\mathrm{Br} J$ Dermatol 2002; 146 Suppl 61: 1-6.

13. Hamid O, Robert C, Daud A, Hodi FS, Hwu WJ, Kefford R, et al. Safety and tumor responses with lambrolizumab (anti-PD-1) in melanoma. N Engl J Med 2013; 369: 134-144.

14. Leiter U, Garbe C. Epidemiology of melanoma and nonmelanoma skin cancer-the role of sunlight. Adv Exp Med Biol 2008; 624: 89-103.

15. Gloster HM, Brodland DG. The epidemiology of skin cancer. Dermatol Surg 1996; 22: 217-226.

16. Lomas A, Leonardi-Bee J, Bath-Hextall F. A systematic review of worldwide incidence of nonmelanoma skin cancer. $\mathrm{Br} J$ Dermatol 2012; 166: 1069-1080.

17. Rogers HW, Weinstock MA, Feldman SR, Coldiron BM. Incidence estimate of nonmelanoma skin cancer (keratinocyte carcinomas) in the us population, 2012. JAMA Dermatol 2015; 151: 1081-1086.

18. Goldstein AM, Tucker MA. Etiology, epidemiology, risk factors, and public health issues of melanoma. Curr Opin Oncol 1993; 5: 358-363.

19. Marks R. An overview of skin cancers. Cancer 1995; 75 (2 Suppl): 607-612.

20. Australian Institute of Health and Welfare. Cancer in Australia. 2001. [2004 December]. Available from: https://www.aihw.gov. au/getmedia/f35edb9c-a103-46de-9093-081ad4af7065/ca01. pdf.aspx?inline=true

21. Australian Institute of Health and. Health system expenditures on cancer and other neoplasms in Australia, 2000-01. Health system expenditures on cancer and other neoplasms in Australia, 2000-01. [cited 2005 May 26]. Available from: https://www. aihw.gov.au/reports/health-welfare-expenditure/health-systemexpenditures-cancer-2000-01/contents/table-of-contents
22. Boi S, Cristofolini M, Micciolo R, Polla E, Palma PD. Epidemiology of Skin Tumors: Data from the Cutaneous Cancer Registry in Trentino, Italy. J Cutan Med Surg 2003; 7: 300-305.

23. Levi F, Te VC, Randimbison L, Erler G, La Vecchia C. Trends in skin cancer incidence in Vaud: An update, 1976-1998. Eur J Cancer Prev 2001; 10: 371-373.

24. Fitzpatrick D, Gavin A, Middleton R, Catney D. Cancer in Northern Ireland 1993-2001: A Comprehensive Report. N. Ireland: N. Ireland Cancer Registry, Queen's University Belfast, 2004.

25. Ichihashi $M$, Naruse $K$, Harada $S$, Nagano T, Nakamura T, Suzuki T, et al. Trends in nonmelanoma skin cancer in Japan. Recent Results Cancer Res 1995; 139: 263-273.

26. Koh D, Wang H, Lee J, Chia KS, Lee HP, Goh CL. Basal cell carcinoma, squamous cell carcinoma and melanoma of the skin: analysis of the Singapore Cancer Registry data 1968-97. Br J Dermatol 2003; 148: 1161-1166.

27. Al-Maghrabi JA, Al-Ghamdi AS, Elhakeem HA. Pattern of skin cancer in southwestern Saudi Arabia. Saudi Med J 2004; 25: 776-779.

28. Takemiya M, Ohtsuka H, Miki Y. The relationship between solar keratoses and squamous cell carcinomas among Japanese. J Dermatol 1990; 17: 342-346.

29. Woodhead AD, Setlow RB, Tanaka M. Environmental factors in nonmelanoma and melanoma skin cancer. J Epidemiol 1999; 9 (6 Suppl): S102-S114.

30. Walder BK, Robertson MR, Jeremy D. Skin cancer and immunosuppression. Lancet 1971; 298: 1282-1283.

31. Shahi UP, Fernandes P, Shukla NK, Chander S, Rath GK. Electron beam irradiation in treatment of skin carcinoma. Indian J Cancer 1989; 26: 41-45.

32. Dhir A, Orengo I, Bruce S, Kolbusz R V., Alford E, Goldberg L. Basal cell carcinoma on the scalp of an indian patient. Dermatologic Surg 1995; 21: 247-250.

33. Darby SC, Scotto J, Fears TR, Fraumeni JF. Incidence of Nonmelanoma Skin Cancer in the United States. Biometrics 1984; 40: 875 .

34. Armstrong BK, Kricker A. Skin cancer. Dermatologic Clinics 1995; 13: 583-594.

35. Hall HI, Miller DR, Rogers JD, Bewerse B. Update on the incidence and mortality from melanoma in the United States. $J$ Am Acad Dermatol 1999; 40: 35-42.

36. Naruse K, Ueda M, Nagano T, Suzuki T, Harada S, Imaizumi $\mathrm{K}$, et al. Prevalence of actinic keratosis in Japan. J Dermatol Sci 1997; 15: 183-187.

37. Harris RB, Griffith K, Moon TE. Trends in the incidence of nonmelanoma skin cancers in southeastern Arizona, 1985-1996. J Am Acad Dermatol 2001; 45: 528-536.

38. Mora RG, Perniciaro C. Cancer of the skin in blacks. I. A review of 163 black patients with cutaneous squamous cell carcinoma. Journal of the American Academy of Dermatology 1981; 5 : 535-543.

39. Fleming ID, Barnawell JR, Burlison PE, Rankin JS. Skin cancer in black patients. Cancer 1975; 35: 600-605.

40. Crowley NJ, Dodge R, Vollmer RT, Seigler HF. Malignant melanoma in black Americans. A trend toward improved survival. Arch Surg 1991; 126: 1359-1364.

41. Mora RG, Burris R. Cancer of the skin in blacks: A review of 128 patients with basal-cell carcinoma. Cancer 1981; 47: $1436-1438$ 
42. Budhraja SN, Pillai VC, Periyanayagam WJ, Kaushik SP, Bedi BM. Malignant neoplasms of the skin in Pondicherry (a study of 102 cases). Indian J Cancer 1972; 9: 284-195.

43. Chakravorty RC, Dutta-Choudhuri R. Malignant neoplasms of the skin in Eastern India. Indian J Cancer 1968; 5: 133-144.

44. Paymaster JC, Talwalkar G V, Gangadharan P. Carcinomas and malignant melanomas of the skin in Western India. J R Coll Surg Edinb 1971; 16: 166-173.
45. Rosso S, Zanetti R, Martinez C, Tormo MJ, Schraub S, Sancho-Garnier H, et al. The multicentre south European study "Helios" II: Different sun exposure patterns in the aetiology of basal cell and squamous cell carcinomas of the skin. Br J Cancer 1996; 73: 1447-1454.

46. Rowe DE, Carroll RJ, Day CL. Prognostic factors for local recurrence, metastasis, and survival rates in squamous cell carcinoma of the skin, ear, and lip: Implications for treatment modality selection. J Am Acad Dermatol 1992; 26: 976-990. 